\title{
Prospective Scenarios: Sucre, Territory of Peace and Development 2030
}

\author{
Escenarios prospectivos: Sucre, Territorio de Paz y Desarrollo 2030
}

\author{
Oswaldo Calao-Paternina \\ Fundación Tecnalia Research and Innovation - Colombia \\ ORCID iD: https://orcid.org/0000-0002-5332-205X \\ oswaldocalao@hotmail.com
}

Fecha de recepción: 22/07/2021

Fecha de evaluación: 19/08/2021

Fecha de aceptación: 26/09/2021

Cómo citar: Calao-Paternina, O. (2021). Prospective Scenarios: Sucre, Territory of Peace and Development 2030. Revista Cientifica Anfibios, 4(2), 84-94. https://doi.org/10.37979/afb.2021v4n2.98

\begin{abstract}
Once a war conflict has been overcome, uncertainty always arises regarding what awaits the territories that left the violence and its development behind. Hence, it is necessary to propose the scenarios that may occur in the near future in order to define actions capable of building lasting peace and sustainable development. In this sense, the main objective of this paper is to do a prospective exercise referring to the probable scenarios for the Department of Sucre, Colombia, in its path of overcoming war, scope of peace and territorial development. The results indicate that the wager scenario, called «A treasure of incomparable beauty», will be the way to achieve a territory of peace and development in the department of Sucre.
\end{abstract}

\section{Keywords}

Conflict; post-conflict; stakeholders; scenarios; territorial development

\section{Resumen}

Una vez superado un conflicto bélico, siempre surge la incertidumbre sobre lo que les espera a los territorios que dejaron atrás la violencia y su desarrollo. De ahí que sea necesario plantear los escenarios que pueden darse en un futuro próximo para definir acciones capaces de construir una paz duradera y un desarrollo sostenible. En este sentido, el objetivo principal de este trabajo es hacer un ejercicio prospectivo referido a los escenarios probables para el Departamento de Sucre, Colombia, en su camino de superación de la guerra, alcance de la paz y desarrollo territorial. Los resultados indican que el escenario de la apuesta, denominado "Un tesoro de incomparable belleza", será el camino para lograr un territorio de paz y desarrollo en el departamento de Sucre.

Palabras clave

Conflicto; posconflicto; actores; escenarios; desarrollo territorial 


\section{Introduction}

Traditional planning is essentially retrospective, since the objectives pursued are largely determined by what happens in the present and has happened in the territory where it is planned (EFF, 2005). On the contrary, as for Prospective planning, the essentials of the future are yet to be written: the stakeholders who are determined to fight for the success of their projects have to build it (Durance, 2011). When there is conflict between two groups, be it over territory, resources or values, there is also always a one-sided take on the past and present (Milojevic, 2008) and this evidently influences the future.

Colombia has been immersed in different conflicts, from the moment of its independence and probably before that as well, during colonization. In that sense, the closest antecedent to our current era is the emergence of the Revolutionary Armed Forces of Colombia (FARC in Spanish) and the National Liberation Army (ELN in Spanish). It was the period known as 'La Violencia', which, between 1948 and 1958, pitted the conservative and liberal parties against each other, thus causing for tens of thousands of deaths and hundreds of thousands of displaced citizens. These situations were overcome through the National Front in 1958, which alternated power between conservatives and liberals until 1974. However, not all combatants accepted reconciliation and many went to assemble groups of bandits capable of controlling part of the national territory, becoming constituted into what was then known as "independent republics within the Colombian territory" (González, 2017).

Originally linked to the Colombian Communist Party, the FARC was born in 1964, and a year later, in 1965, the ELN sprung up inspired by the Cuban Revolution. As early as 1963, the EPL (Popular Liberation Army), a Maoist inclination group that laid down its arms in 1991, had emerged. Other movements subsequently sprouted, such as the M-19 (1973) and the indigenous armed group Quintín Lame (1983), they were also incorporated civilian life in the early 1990s (Peñaranda \& Guerrero, 1999).

The department of Sucre is located in the north of Colombia and has an area of 10,670 $\mathrm{km}^{2}$ and a population of 949,252 inhabitants. In this Department, the process was aggravated by the emergence of armed insurgency in the region in the early $80 \mathrm{~s}$, which found in the mountain of San Jacinto, an area of difficult access, a suitable place for refuge. The outlook would become even more complex in the $90 \mathrm{~s}$, with the emergence of self-defense groups (known as AUC). In 1997 violence increased in the region after the incursion of the North Bloc of the AUC by Rodrigo Tovar Pupo, a.k.a. "Jorge 40", who ordered the murder of several leaders in the region. According to data from the report of the National Commission for Reparation and Reconciliation, between 1997 and 2009, in this region, illegal armed groups committed 45 massacres (including Macayepo, Mampuján and El Salado) and displaced 219,603 people, while 242 were victimized by land mines. (CNRR, 2012).

For its part, the FARC strengthened its social, military, political and economic presence in the area, taking as targets of its actions, in addition to the Armed Forces and Police, the civilian population as well as social organizations. The Peace Process between the government and the FARC initiated in 2012 and ended, in its first phase, with the signing of the Final Agreement on September $26^{\text {th }}, 2016$ in the city of Cartagena de Indias. However, it cannot be said that a confrontation of more than fifty years would wind down with the end of the armed conflict. Peace agreements are a first step in a peacebuilding process that, according to Rafael Pardo, Colombian post-conflict minister, can take up to 15 years to reach the entire territory

Given the conditions described above, this article becomes a valuable opportunity to produce proposals that help make the Department of Sucre a Territory of Peace and land development, where opportunities for progress are generated, which allow for an improvement of the living conditions of all its inhabitants (Moro \& Reyes, 2010). For this, it is necessary to propose prospective scenarios that indicate the necessary stakeholders and draw lines of action upon which to direct the Department into a promising future. In this sense, the main objective of this article is to bring forth a prospective exercise towards 2030 referring to the Department of Sucre and its territorial development, where different future contexts in this region are addressed, identifying the most probable. 


\section{Theoretical Background}

Prospective approach, scenario creation and territorial development

The perspective, as will be shown, considers the future as a multiple space and, therefore, as part of the existence of possible alternative futures, which assigns them a degree of probability of occurrence and convenience (Bas, 1999). However, to achieve this change towards a positive future, it is necessary to consider key arrays depicting the developing dimensions of change to reveal future trends with extraordinary accuracy (Molitor, 2003).

On the other hand, according to Taleb (2008), these are unpredictable situations or events, that is, they arise in an inappropriate or unexpected way. Therefore, they have a strong impact on the environment, and, on occasion, can have global repercussions.

Hence, the Prospective approach is very closely related to the concepts of strategy and planning, which, in turn, are linked to each other and give rise to a fundamental term in the field of study proposed herein, namely: Strategic Planning, Management Planning and Strategic Prospective Approach (Michel Godet, 2000). Under this consideration, this study adopts the French School of Strategy and Prospective Approach as a theoretical reference. This school of thought was born in the sixties, under the leadership of Bertrand de Jouvenel and Michel Godet. It is based on humanism, to propose that the future can be created and modified by the actions of social stakeholders, whether individual or organized, and proposes studies that characterize future society in its various approaches: social, economic and cultural (Quinteros \& Hamann, 2017)

For Godet, regarding territorial development, the essence of the Prospective Process lies in a set of three elements. He calls it the "Greek triangle", and it is made up of anticipation, appropriation and action. Anticipation is equivalent, in practice, to the production of images of the future, generally through the method of scenarios; Appropriation is the process of interlocution with social stakeholders, to share the images of the future by a social group, specifically with methods that stimulate strategic conversations between social stakeholders, as well as participation and public communication. Meanwhile, the action has to do with the implementation of a plan or program that translates the images of the future into real events (Godet, 2000).

We use the French school of foresight because it has a more humanistic vision of the future than others. This means that the main stakeholders within the territories must work together in such a way that the best possible scenarios are achieved, instead of concentrating on enhancing the individual capacities of each stakeholder.

\section{Theoretical Approaches to Peace}

In the Political Constitution of Colombia, peace is enshrined as a fundamental right, and peaceful coexistence as a goal of the State. But peace is a broader concept than the lack of war, of armed conflict. To Ramírez (2014), it cannot be expected that there will be peace in Colombia if there is inequality and the necessary conditions are not created so that the population can have a dignified life.

One of the most prominent theorists in this conceptual line on peace is Johan Galtung, who, in the second post-war period, created the Center of Specialized Studies for Peace. One of the fundamental contributions of this Center has to do precisely with having developed the concept of peace in a broad way. To be more exact, Galtung's theory raises four basic needs (survival, well-being, identity and freedom), which must be met in every society that wants to live in peaceful conditions. However, each of them has a denial (mortality, suffering, alienation and repression, in their respective order).

On the other hand, Galtung (1969) raises the idea of peace from three simple principles: 1) the term 'peace' will be used for social purposes, at least verbally, as agreed by many, if not necessarily by the majority; 2) such social goals can be complex and difficult, but not impossible to achieve, and 3) the declaration of peace as the absence of violence will remain valid.

For Galtung (2003), the concept of violence has a triple dimension, namely: direct, structural and cultural. Thus, the direct one is manifest violence, the most obvious. Its manifestation can be generally physical, verbal or psychological. On 
the other hand, the structural one is violence intrinsic to the social, political and economic systems, that is, the same ones that govern societies, states and the world. Its relationship with direct violence is proportional. Finally, cultural violence encompasses all aspects of culture, in the symbolic scope of our experience, that can be used to justify or legitimize direct or structural violence.

That said, it is now convenient to look at the figures related to violence in the specific case of the Department of Sucre. According to the figures of the Single Registry for Victims, 298,090 deaths have been registered as caused by violence, of which 288,388 are a direct consequence of the armed conflict. This means that, with a population of 868,403 inhabitants (DANE, 2017), the victims represent $33.2 \%$ of the Department's population. These shocking figures are the reflection of different dynamics and stakeholders that have developed in the context of the armed conflict.

Given the large number of victims from the conflict, the development of the Peace Process between the Colombian government and the FARC appeared as a valuable opportunity to bring peace to the Department of Sucre; this is what came to be called the Special Jurisdiction for Peace (JEP in Spanish). In fact, from these negotiations, a justice mechanism was established for crimes committed within the framework of an internal conflict that has been taking place for more than 50 years, leaving behind more than 220,000 deaths and over seven million people affected, where JEP is it will focus especially on the most serious crimes (Cosoy, 2015).

In general, a balance of these two years of peace is positive in terms of reduced confrontations, deaths and violence, and lays the challenges of implementation in economic, social and security terms down on the table. Betín (2018), however, states that it is not entirely clear how Sucre's territory will face this process.

\section{Methodology}

The methodology put forth is exploratory, framed within the qualitative paradigm, understanding the competitive dynamics of the territory and establishing future development scenarios. As a tool for data analysis, the Cross-Impact Matrices System (SMIC) was implemented, which allows for the evaluation of changes in the probabilities of an event system due to the occurrence of one of the constituent events (Mojica, 2005).

The hypotheses, as mentioned, were taken from the objectives that were used in the game of stakeholders, while the probabilities (simple/ if conditional/ but conditional) were extracted from 24 surveys given to the same number of experts on conflict and Post-conflict issues, who have lived, on a first-hand basis, through more than fifty years of fighting by the country's different groups outside the law. These surveys were prepared based on questions related to the hypotheses, about what the Department of Sucre is expected to become in the coming years.

Subsequently, from among the various scenarios presented by SMIC, the one that was considered most appropriate was chosen, which was called the "Wager Scenario", and which will be the objective of the Strategic Plan to be followed. The scenario with the highest probability was called the "Trend Scenario" which reflects the situation that would occur in the future if all the variables followed their evolution, as is currently observed (Ibarra, 2014).

As for the Matrix of Importance and Governance (IGO), according to Mojica (2005), one can study the characteristics and conditions of the actions upon which the wager scenario will be built. First, it should be clarified that the actions are proposed by experts, based on a brainstorm. The role of the experts is to specify the relationship of each action with respect to their corresponding objective, as well as the domain of the different actions. All suggestions made by the experts are accepted, but only those that can be called "key actions" will be implemented. These were selected according to two criteria: importance and governance, both based on a scale from 0 to 100 , where figures closer to 100 indicate higher importance and control.

Finally, the design of the probable or trend scenario by 2030 was developed through the tool of axes by Peter Schwarz, which is an alternative way of building scenarios in exercises and prospective studies. As the results are shown through these scenarios, one can reflect on various possibilities around the future, evaluate and anticipate their consequences, identify risks and opportunities, as well as design strategies that allow for goals to be set (Gandara, 2014). 


\section{Findings}

Below are the results obtained after analyzing two dimensions: firstly, the three principles that give rise the idea of peace proposes by Galtung (1969); secondly, the factors and variables that come into play when making a projection of the possible scenarios that are offered in the future for the Department of Sucre within the framework of the Post-Conflict.

\section{Approach of Scenarios for Sucre as a Territory of Peace towards 2030}

In order to put this section together, the results of a morphological analysis previously carried out were taken as a basis, where key variables or strategic variables were identified upon which the scenarios for Sucre as a territory of peace will be built, as of 2030. They also had taken into account the results of the game of stakeholders with their interests, their degree of power and their level of ambivalence regarding the fulfillment of the necessary actions to reach the "Probable Scenario" that would allow for Sucre to become a territory of peace throughout the next decade.

\section{Expert Qualification}

The trends of hypothesis occurrence were cataloged as follows: "Very Strong", corresponding to a probability of occurrence of more than $90 \%$ for said hypothesis. "Strong" is the trend that monopolizes a probability of occurrence below $90 \%$, but above $80 \%$. A "Moderate" trend would have a probability of occurrence of less than $80 \%$, but more than $50 \%$. In the same vein, a "Weak" trend is between $20 \%$ and $50 \%$, while less than $20 \%$ is an "Unlikely" trend.

For its part, the SMIC-PROB-EXPERT methodology, adapted for the study, established six different hypotheses, each with its average probability of occurrence. The hypothesis of the application of the JEP legal framework ranks first with $65.38 \%$. Coming in second, social relations would have an average occurrence of $47.71 \%$. Social impact is associated with an average of $45.00 \%$ and public security would reach an average of $59.38 \%$. As for the hypothesis of the peace budget, an average of $44.25 \%$ would occur, while the assistance of institutions garners $44.04 \%$.
Once the analysis of data pulled up by the SMIC-PROB-EXPERT software has been carried out, it is possible to exhibit that the "probably" scenario comes in first (000000); the second analysis scenario is that of the wager (111111); while the third (111101) and the fourth places (100010) go to the alternative scenario. The numbers alongside the scenarios are the result of the hypotheses that were implemented to build them. The scenarios subjected to analysis were those whose cumulative probability is approximately $75 \%$, that is, the scenarios whose hypotheses are more likely to occur. To determine the configuration of the scenario, timelines will be used, where the occurrence of the hypotheses will be pinpointed.

\section{Strategies needed to help make the Department of Sucre a Territory of Peace by 2030}

Once the assessments have been made regarding the strategic actions, an average figure from the results of importance and governance has been calculated. The actions will be considered immediate if they are above such an average figure, while, if they fall below that level, they can be classified as medium and long-term actions.

Taking the results of the IGO plan into consideration, it is possible to propose some immediate actions that allow for a step towards peace in each given hypothesis. These are actions that must be implemented urgently to achieve the following objectives: a JEP legal framework request where an office is set up in the Department for a follow-up on the actions of comprehensive reparation and non-repetition (with support from institutions to create strategic alliances that lead to the participation of the country's economic conglomerate to support the commercial initiatives arising from the victims of the conflict); a peace budget that will grant tax breaks to national companies that link the victims of conflicts into their organizations and manage resources from the Department of Sucre related to the post-conflict process. The last key factor is Public Security where program development will be encouraged towards conflict prevention.

On the other hand, the medium and long term actions should also be taken into account, since it is difficult to reach a wager scenario through sim- 
ple short-term actions, which are the rest of the actions that can be observed in the IGO matrix.

\section{Narration of the Scenarios}

Once the projections have been made, the different scenarios to be expected can subsequent- ly be described upon confirmation of each of the hypotheses raised. The findings contemplate 4 scenarios that are provided by 6 combinations of key success factors, thus achieving a probability of occurrence according to the implementation of each, its execution and the level of appropriation by the community, which can be observed in the table below.

Table 1. Proposed Scenarios.

\begin{tabular}{|c|c|c|c|c|}
\hline $\mathbf{N}^{o}$ & Scenario name & $\begin{array}{l}\text { Probability } \\
\text { of } \\
\text { occurrence }\end{array}$ & $\begin{array}{l}\text { Kind of } \\
\text { scenario }\end{array}$ & Description \\
\hline 1 & $\begin{array}{c}\text { The Grand Marshal } \\
\text { of Ayacucho }\end{array}$ & $30.5 \%$ & Trend & $\begin{array}{l}\text { Mainstream media demonized the process and the conflict } \\
\text { was reactivated. Citizens stopped traveling, resources for } \\
\text { peace went to war, many people from Sucre were forced } \\
\text { to look for new horizons where they could develop their } \\
\text { life projects. }\end{array}$ \\
\hline 2 & $\begin{array}{l}\text { A treasure of beauty } \\
\text { without equal }\end{array}$ & $26.3 \%$ & Bet & $\begin{array}{l}\text { The conflict ends, the FARC turns in their weapons, re- } \\
\text { sources are allocated for investment in education and } \\
\text { healthcare, the territory's business apparatus is reactivated } \\
\text { and territorial development is achieved. }\end{array}$ \\
\hline 3 & $\begin{array}{l}\text { This land is a mon- } \\
\text { ument to your mem- } \\
\text { ory }\end{array}$ & $17 \%$ & Alternative & $\begin{array}{l}\text { The end of the conflict is accomplished with a partial ful- } \\
\text { fillment of the initial agreements and the change begins. } \\
\text { However, a new government, with the help of traditional } \\
\text { media, increases the war budget and guarantees security } \\
\text { under strong retaliation from residual subversive groups }\end{array}$ \\
\hline 4 & $\begin{array}{l}\text { Your people will } \\
\text { follow you in peace }\end{array}$ & $1.6 \%$ & Alternative & $\begin{array}{l}\text { The President of Colombia makes some objections to the } \\
\text { initial agreements; however, some conditions are achieved } \\
\text { to materialize peace in the territory. The resources that } \\
\text { would initially be allocated to education and healthcare } \\
\text { are rerouted to reinforce security measures in the territory, } \\
\text { which is finally occupied by groups above the law, many } \\
\text { people of Sucre are forced to look for new horizons where } \\
\text { they could develop their life projects. }\end{array}$ \\
\hline
\end{tabular}

Source: Prepared by the authors.

\section{Trend scenario (000000): “The Grand Marshal of Ayacucho"; Probability of occurrence of} $30.5 \%$.

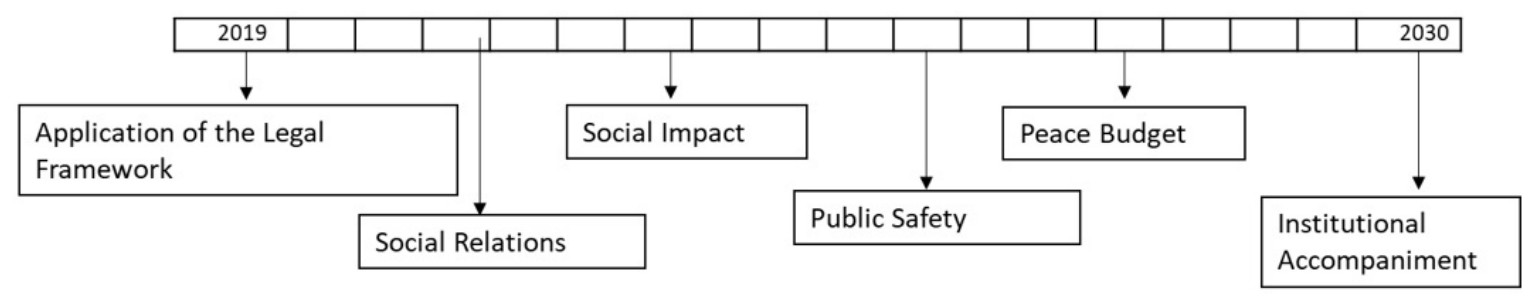

Figure 1. Trend scenario

Source: Prepared by the authors

This scenario takes the moniker of General Sucre, known as "The Grand Marshal of Ayacucho". In 2019, mainstream media, influenced by far-right political groups, used their editorial lines to demonize the process and create an environment that did not favor the possibility of turning the page of a conflict that had lasted more than fifty years. This situation led to the reactivation of the conflict in many regions and to a confrontational discourse by far-right groups. Drug traffickers, the ELN and paramilitary armies violently lashed out at several municipalities, and the reconstituted FARC expanded their scope of influence and modified their mode of action, focusing on cities 
and aiming their terrorist attacks not only against the Armed Forces, but also against people not related to the conflict. As a result of this, foreign investors withdrew from the country, tourism ceased to be a business opportunity and the per capita income of the people of Sucre was reduced to a third of the national average.

Citizens stopped traveling on the country's roads and the perception of insecurity exceeded historical highs. The resources that were previously dedicated to post-conflict were not invested in education or healthcare, but in ramping up the country's military weaponry, while mainstream media depicted this as a noble purpose and as intentions of defending ordinary citizens, which is consistent with the rhetoric of far-right political groups, who, at the same time, took advantage of this state of confusion to create and revive controversial reforms such as a presidential re-election. All of the above had the effect of transforming the Department of Sucre and the whole country into a territory where there were no possibilities of well-being and development, so many people from Sucre were forced to look for new horizons where they could develop their life projects.

\section{Scenario bet (111111): “A treasure of beauty without equal". Probability of occurrence of 26.3\%,}

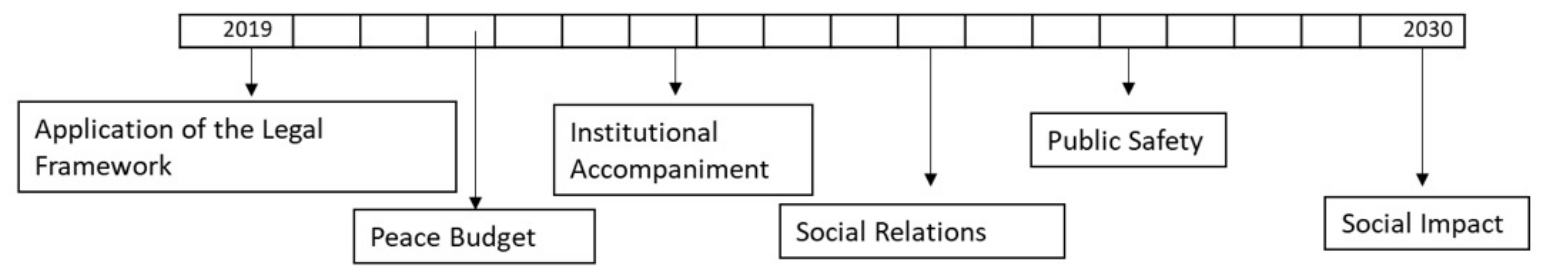

Figure 2. Wager scenario

Source: Prepared by the authors

This scenario takes its name from a stanza in the anthem of the Department of Sucre. In the year 2019, and after living through a conflict of more than fifty years with the FARC, the Department of Sucre, like the rest of the country, despite the constant attacks on the Peace Process by groups outside the law, the right-wing political groups and the reconstituted FARC saw how President Iván Duque Márquez signed the JEP legal framework that guaranteed Truth, Justice, Reparation and Non-repetition for the victims of the armed conflict. This act was support by churches, victims, academics, the UN, several NGOs, and left-wing political parties. Despite the intentions of reducing the peace budget by the State, organizations of victims and peasants raised their voices to show the benefits of living in an environment where one of the stakeholders in the conflict laid down their weapons.

Thanks to this, they managed to ensure that the UN and the countries that vouch for the Peace Process exert the necessary pressure to fully comply with the commitments provided by the signed agreement, especially in relation to the resources that guaranteed Truth, Justice, Reparation and Non-Repetition for the victims of the conflict. The government did everything possible to fulfill its electoral promises and, thanks to the fact that the FARC turned in their weapons, institutional support was achieved in the 22 municipalities of the Department of Sucre, where outlawed groups, international drug cartels and the FARC were locally reconstituted. By decreasing insecurity, peasant organizations and businessmen in the Department were able to establish themselves in a safer environment and thrive economically and socia1ly. The security of the country is now recognized as it is free of outlaw groups, which provides guarantees for the international community.

The Department of Sucre and its municipalities created projects and initiatives that were supported by NGOs and the Red Cross, which helped to obtain more resources for the maintenance of the Territorial Training and Reincorporation Spaces and the New Points of Regrouping. The Military Forces provided security to peasant organizations and victims, which was widely approved by the international community. For their part, foreign investors, realizing that a safe environment was being provided, decided to bet on the generation of development, which resulted in an increase in the per capita income of the citizens from the Department of Sucre, to the point that it reached national average levels. 
Alternate scenario 1 (111101): “This land is a monument to your memory.” Probability of occurrence of $17 \%$.

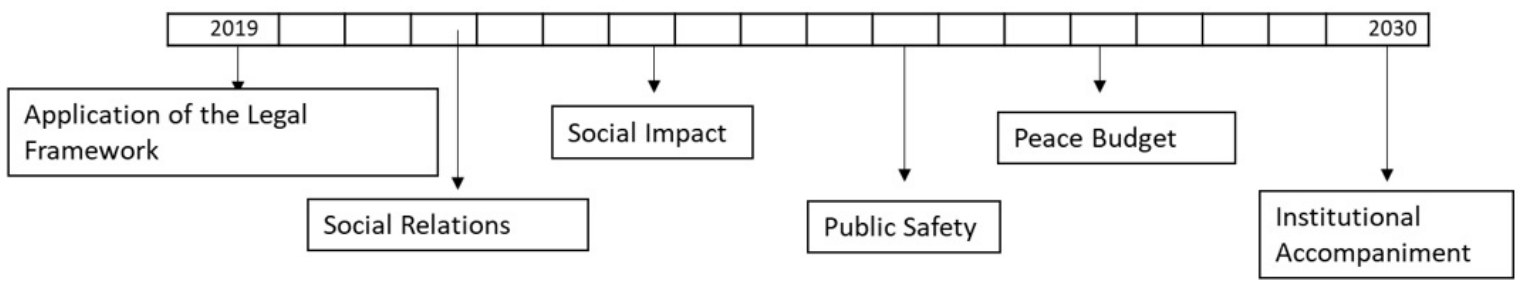

Figure 3. Alternate scenario

Source: Prepared by the authors

The name of this scenario is taken from a stanza in the anthem of the Department of Sucre and refers to the hero appointed by the Department. After experiencing the armed conflict with the oldest guerrilla in the world, the Department of Sucre, like the rest of the country, welcomed the commitments defined in the legislative act of the JEP, signed by President Iván Duque Márquez. The government allocated the resources to give continuity to the JEP legislative framework and those resources were invested in projects and initiatives in the Department of Sucre and its municipalities. This facilitated a better operation of the economy, which led to investment initiatives and the creation of new companies that helped reduce business informality, which, in turn, resul- ted in an increase in the per capita income of the citizens of the Department of Sucre, to the point that it reached national average levels.

Unfortunately, the government back in that day, in response to the actions of groups outside the law, increased the budget for the defense of national security. And the mainstream media, saw these intentions of defending ordinary citizens as a noble purpose, which is consistent with the rhetoric of far-right political groups. While, on an internal basis, it guaranteed peace of mind for the communities and the business owners that were previously subjected to the groups outside the law.

Alternate scenario 2 (100010): "Your people will follow you in peace". Probability of occurrence of $1.6 \%$

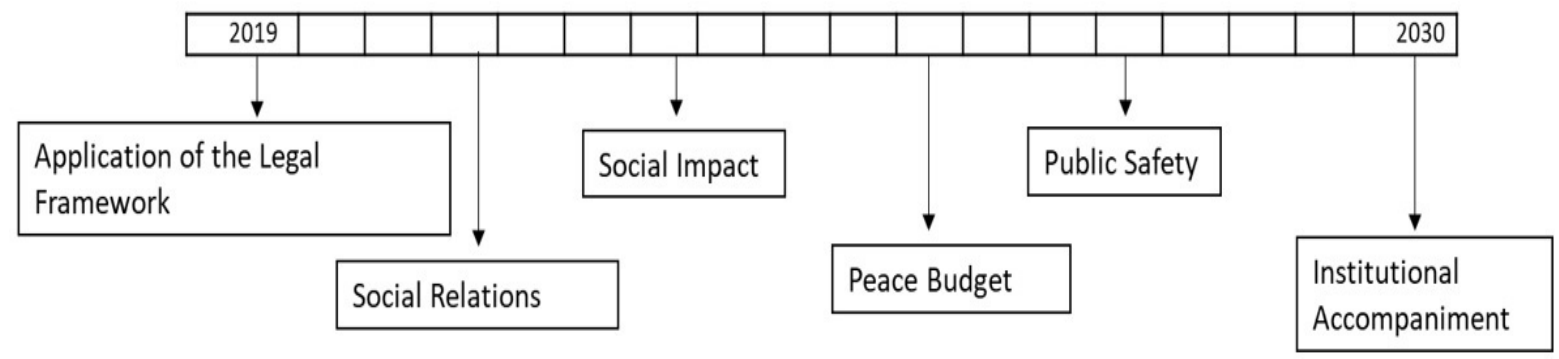

Figure 4. Alternate scenario 2

Source: Prepared by the authors

This scenario is named after one of the stanzas in the anthem of the Department of Sucre. In the year 2019, the Department of Sucre, like the rest of the country, despite living through a conflict of more than 50 years with the FARC, is faced with a situation where the President of the Republic, Iván Duque Márquez, at the request of his party, makes six objections to the JEP legal framework that guarantees Truth, Justice, Reparation and
Non-repetition of the victims of the armed conflict. Business informality grew and the per capita income of the Department of Sucre was reduced to one third of the national average. Public safety was affected by the incursion of international drug trafficking groups.

With support from the churches and from the peace process guarantor countries, the government partially agreed to comply with former 
guerrilla fighters who were in the Territorial Training and Reincorporation Spaces and in the New Points of Regrouping, which could prevent them from rearming and joining other groups outside the law, such as the ELN and the reconstituted FARC. Citizens regretted the fact that, instead of using more resources for healthcare and education, expenditure on weapons purchases was increased to reinforce security measures and support the more than 22 municipalities of the Department that had been occupied by groups above the law, the reconstituted FARC and international drug trafficking groups. With these results, foreign investment moved away from the Department of Sucre and its inhabitants had to look for new horizons in order to move forward.

\section{Conclusion and Discussions}

In the scenarios proposed for the Department of Sucre as a Territory of Peace by 2030 , the results obtained from the workshops carried out with the experts were outlined and four possible scenarios were proposed. The wager scenario, called «A treasure of incomparable beauty», has as its main characteristic the fulfillment of the six hypotheses that comprise it and shows the representation of the country and the Department of Sucre as territories that have achieved peace thanks to the commitments. Likewise, law enforcement agencies were present in the $22 \mathrm{mu}-$ nicipalities of the Sucre Department where there were groups outside the law, which greatly increased the confidence of inhabitants from these territories in the local and national government. In addition, as a result of the assistance provided by the State, the homicide rate was lower than the national percentage, which generated a greater sense of security leading up to the arrival of foreign investments to the Department of Sucre, as well as a notable boost to new directions, towards generating development and achieve per capita income at the country level.
In short, this is the scenario that the Department of Sucre should wager on. However, for this to happen, the will of all the stakeholders brought up in the study is required, taking into account that the changes necessary to make Sucre a territory of peace will not occur if no actions are taken, from now on, aimed at promoting the materialization of such a scenario. This demonstrates the importance it has for the system, so it is essential that the Department meets the rest of the system's objectives, so that resources can be accomplished out of the establishment of projects and initiatives that may cover the expenses of the process.

The above allows for a discussion on the subject in question. In the first place, studies are needed in order to address the understanding of conflicts more broadly, that is, what the reasons for these conflicts are, with a special emphasis on Colombia.

Another important aspect where future studies could be considered is how institutions can be linked to a peace process or a post-conflict setting, due to the fundamental role that institutions play in today's society and how conflicts can be understood from such institutions.

\section{Acknowledgements}

The researchers are grateful for the support from the high training agreement of the General System of Royalties - GRS, Number 0682, signed between Colciencias and the Government of Sucre, through which Agreement 224 of 2015 between Colciencias and Universidad Tecnológica de Technological, in Cartagena de Indias was signed for the formation of human talent at the Master's degree level. In this regard, professors, residents of the Department, members of the Marine Corps, members of the National Police, merchants, and social leaders are thanked. The reviewers and editors are also thanked for their helpful comments.

\section{Conflict of Interest Statement}

This document does not generate any conflict of interest

\section{References}

Baena Paz, G. (2004). Prospectiva política. Guía para su comprensión y práctica, México: Universidad Nacional Autónoma de México. 
Bas, E. \& Guilló, M. (eds.). (2016). Prospectiva e innovación. Vol. I. Visiones. Madrid/México: Plaza y Valdés

Bas, E. (1999). Prospectiva: cómo usar el pensamiento sobre el futuro. Bogotá: Ariel.

Berger, G. (2003). La actitud Prospectiva, Revista Universidad de Guadalajara, 26, 33-36. https://biblioteca.udgvirtual.udg.mx/jspui/bitstream/123456789/392/1/La\%20actitud\%20prospectiva.pdf

Betín, T. (24 de noviembre de 2018). Los retos del Acuerdo de Paz dos años después. Barranquilla: El Heraldo. Recuperado de https://www.elheraldo.co/politica/los-retos-del-acuerdo-de-pazdos-anos-despues-569730

Comisión Nacional de Reparación y Reconciliación. (2012). Los 100 municipios críticos del conflicto armado. Recuperado de https://verdadabierta.com/una-lupa-al-conflicto/

Cosoy, N. (24 de septiembre de 2015). En qué consiste el pacto entre las FARC y el gobierno de Colombia que los deja a un paso de la paz. Bogotá: BBC Mundo.

Durance, P. (2011). La Prospectiva estratégica. Unesco, 14.

Fundación Eduardo Frei. (2005). Cuaderno 3: Prospectiva y construcción de escenarios para el desarrollo territorial, 92.

Galtung, J. (2003). Violencia cultural, Documento No. 14, Bizkaia, Gernika Gogoratuz,

Gándara, G. (2014), “Capítulo 1. Proceso Metodológico para estudios de futuro”, en Gándara y Osorio, Métodos prospectivos: Manual para el estudio y construcción del futuro, México, Paidós.

Godet, M. (2000). La caja de herramientas de la Prospectiva estratégica. Cuaderno número 5.

González, A. (2017). Relación entre conflicto y posconflicto: Colombia y los Acuerdos de Paz. Instituto Español de Estudios Estratégicos. Recuperado de http://www.ieee.es/Galerias/fichero/ docs_analisis/2017/DIEEEA25-2017_Paz_Colombia_Postconflicto_AGM.pdf

Ibarra, M. (2014). Aplicación y articulación de Herramientas de Planeación. Bogotá: Entrelibro.

Milojevic, I. (2008). Making peace: Kosovo/a and Serbia. Journal of Futures Studies, 13(2), 1-12.

Mojica, F. (2005). La construcción del futuro. Bogotá: Universidad Externado de Colombia.

Mojica, F. (2008). Forecasting y Prospectiva dos alternativas complementarias para adelantarnos al futuro. Universidad Externado, 1-18. Recuperdo de http://www.franciscomojica.com/articulos/adalfut.pdf

Molitor, G. T. (2003). Molitor forecasting model: key dimensions for plotting the patterns of change. Journal of Future Studies, 8(1), 61-72.

Moro, B., I, D. D. P. A., \& Reyes, O. G. (2010). Los Montes de María: Análisis de la conflictividad. Recuperado de https://info.undp.org/docs/pdc/Documents/COL/00058220_Analisis\%20conflcitividad\%20Montes\%20de\%20Maria\%20PDF.pdf

Nasi, C. \& Rettberg, A. (2005). Los estudios sobre conflicto armado y paz. Un campo en evolución permanente. Colombia internacional, (62). Pp. 64 - 85. Recuperado de http://www.redalyc. org/articuloa?id=81206205

Peñaranda, R. y Guerrero, J. (comp.). (1999). De las armas a la política. Bogotá: Tercer Mundo Editores.

Quinteros J. \& Hamann A. (2017) Planeamiento estratégico prospectivo, Métodos MACTOR y SMIC. ECOE Ediciones. 
Ramírez, D. (2014). La paz según Johan Galtung: ¿Cuáles son los elementos que debemos solucionar en Colombia? Pereira: Universidad de Pereira.

Rodríguez, J. (2013). Diseño Prospectivo de Escenarios para la Ciencia, Tecnología e Innovación al 2040. 16(2), 92-105.

Solomón, E. (1978). El arte de la anticipación. Buenos Aires: Editorial Troquel.

Taleb, N. (2008). El Cisne negro. Barcelona: Paidós.

Tous, J. (29 de agosto de 2017). Sucre, en conflicto. Barranquilla: El Heraldo. Retrieved of https:// www.elheraldo.co/politica/sucre-en-conflicto-397139 